\title{
KAJIAN ISLAM TERHADAP SILA KEDUA DALAM PANCASILA SEBAGAI PENJAGA MULTIKULTURALISME
}

\author{
Oleh: Sulistyani Eka Lestari \\ Pengurus AP-HTN/HAN Jawa Timur
}

Email : sulis_usb@yahoo.com

\begin{abstract}
Abstrak
Pancasila sudah lama menjadi ideologi bangsa Indonesia. Meskipun demikian, masih banyak subyek bangsa ini yang tidak menempatkannya sebagai ideologi. Mereka menunjukkan sikap dan perilaku yang berlawanan dengan ideologi. Salah satu sila dalam Pancasila yang dilanggar atau dilecehkannya adalah sila kedua (kemanusiaan yang adil dan beradab). Bentuk perbuatan yang ditunjukkan dengan melecehkan sila kedua dari Pancasila ini adalah radikalisme baik secara individual maupun kelompok. Pancasila sebagai penjaga multikulturalisme hanya disikapi sebagai kumpulan teks yang tidak bermakna.
\end{abstract}

Kata kunci: Pancasila, ideologi, radikalisme, multikulturalisme, Islam

\section{Abstract}

Pancasila has long been the ideology of the Indonesian. Even so, there are still many subjects of this nation that do not place it as an ideology. They show attitudes and behaviors that are contrary to the ideology. One of the principle in Pancasila that was violated or abused was the second principle (fair and civilized humanity). The form of deeds shown by insulting the second principle of the Pancasila is radicalism both individually or in groups. Pancasila as the guardian of multiculturalism is only addressed as a collection of meaningless texts.

Keywords: Pancasila, ideology, radicalism, multiculturalism, Islamic

\section{PENDAHULUAN}

Usia negara (Indonesia) ini dari waktu ke waktu makin tua. Dalam hidup bernegara ini, kita atau setiap subyek bangsa perlu dan bahkan harus sering bertanya, benarkah kebijakan pemerintah (negara) senyatanya memang membebaskan atau menyejahterakan orang miskin, ataukah justru sebaliknya memiskinkan orang miskin?

Pertanyaan itu kemudian bersifat lebih khusus benarkah negara ini benar-benar sudah mengamalkan salah satu sila dari ideologi negara Pancasila yang berbunyi "kemanusiaan yang adil dan beradab"? Tidakkah sila "kemanusiaan yag adil dan beradab" hanya dijadikan sebagai hiasan individual, kultural dan struktural kehidupan kenegaraan? 
Dalam ranah idealitas, Pancasila sebagai falsafah pandangan hidup bangsa, seyogyanya dicerminkan ke dalam prinsip-prinsip nilai dan norma kehidupan dalam berbangsa, bernegara dan berbudaya. ${ }^{1}$ Pancasila sebagai dasar negara ini merupakan filsafat kenegaraan bangsa Indonesia yang menjadi landasan utama semua sistem penyelenggaraan kehidupan bernegara dan bermasyarakat. Ketika di masyarakat masih banyak kondisi buruk, maka diantara yang perlu dipertanyakan adalah ketaatan ideologisnya.

Berkaitan dengan hal itu, ada pepatah berbunyi "sesuatu yang buruk terjadi di masyarakat itu disebabkan oleh kondisi buruk yang mempengaruhinya" (evil causis evil vallacy). Penyakit sosial tidak akan sampai marak atau tumbuh subur di masyarakat kalau tidak dpengaruhi oleh kondisi buruk.

Berbagai bentuk kejahatan atau perilaku radikalistik dari "orang kecil" tidak akan sampai atau mudah merebak dimana-mana kalau di masyarakat tidak tersedia atau "disediakan" akar kriminogen yang menyebabkannya. Mereka tidak akan jadi pemarak kriminalisasi "kemanusiaan yang adil dan beradab" kalau mereka tidak sering dikorbankan oleh sekelompok orang yang hanya suka jadi penghafal, bukan pengamal sila kedua Pancasila.

Sikap dan perilaku patologis terhadap Pancasila tidaklah berdiri sendiri, melainkan ditentukan oleh aspek lainnya. Sikap dan perilaku demikian bukan disebabkan faktor hereditas, tetapi oleh lingkungan atau keadaan buruk yang membuatnya atau mendidiknya agar menjatuhkan pilihan-pilihan yang kontra produktif, irasional, disobyektifitas, dan tidak menghormati harkat manusia lainnya.

Sebagai bahan refleksi, di kota-kota besar belakangan ini sangat gampang dijumpai kasus-kasus yang bertemakan sebagai kejahatan bercorak blue crime, yang nota bene pelakunya berasal dari elemen masyarakat dari kalangan bawah (lower class). Di suatu komunitas yang semula distigma sebagai daerah aman atau tak pernah dirambah kasus kriminalitas, tiba-tiba muncul serombongan orang (preman) yang dengan kejinya melakukan perampokan dan pembunuhan. Pembantu Rumah tangga atau tukang kebon yang semula di-PHK sepihak oleh majikannya bereaksi melakukan pembalasan kepada majikan zalim ini dengan cara sadisme.

Komunitas akar rumput yang kehilangan pondasi ekonominya itu masuk dalam babakan baru kehidupan yang menyakitkan atau menafikan keberdayaannya, yakni kondisi kehidupan serba marjinal dan tidak

${ }^{1}$ Laboratorium Pancasila IKIP Malang, Refleksi Pancasila dalam Pembangunan (Surabaya: Usaha Nasional, 1997). 243. 
memanusiakannya seperti kehilangan pengharapan kelayakan kesejahteraan, dan terpuruk dalam kemiskinan.

Lebih memprihatinkan lagi, misalnya suatu ketika, ada pimpinan daerah yang menyarankan kepada rakyat supaya menyikapi produk kebijakan-kebijakan pemerintah, khususnya yang memberi beban pada masyarakat, dengan sikap arif, iklas berkorban, lapang dada, atau tidak dengan reaksi yang berlebihan, apalagi dengan perlawanan secara radikal.

Suatu permintaan yang (barangkali) wajar dari seorang elitis kekuasaan yang punya obsesi mewujudkan stabilitas atau tertib sosial (social order) di daerahnya. Pimpinan daerah ini tidak ingin wilayahnya dimarakkan oleh aksi-aksi perlawanan massif, yang dinilainya dapat mengganggu ketenangan dan kedamaian, apalagi sampai mengarah pada tumbuhnya horor.

Lain halnya jika bersumber dari realitas ketidakberdayaan rakyat, tentulah permintaan pimpinan daerah itu dianggapnya berlebihan dan melecehkan, karena selain kalau rakyat berniat dan menunjukkan protes, sebenarnya apa yang dilakukan sebagai "hak", di samping sebagai bagian dari atmosfir "manisnya" demokrasi di negeri ini, seperti memberi peluang bagi rakyat melakukan apa yang disebut Norcholis Majid "oposisi cerdas" atas kebijakan pemerintah yang represip, yang merugikan, mendiskriminasikan, dan menyengsarakannya.

Permintaan pemerintah itu juga mengesankan kalau yang akan menjadi pengganggu atau pembuat kekacauan (chaos) seperti radikalisme di tengah masyarakat adalah rakyat kecil yang sedang menolak terhadap kebijakan pemerintah. Seolah-olah mereka inilah yang telah atau sedang berdosa, sehingga layak untuk diingatkan, disadarkan atau ditaubatkan supaya menjadi rakyat yang patuh kepada penguasa (umara'), tidak menempatkan dirinya secara berlawanan (vis a vis) dengan negara, dan selalu tunduk pada perintah penguasa.

Saat diposisikan sebagai pembuat dosa sosial itulah, rakyat kecil identik sudah mendapatkan stigma sebagai komponen bangsa yang anti nasionalisme atau jauh dari sikap mencintai negara atau Pancasila. Pijakan agama yang digunakan "mencintai negara itu bagian dari iman", sehingga diasumsikan siapa yang mau digolongkan dan berhak mendapat stigma sebagai mukmin haruslah menjadi orang yang benar-benar mencintai negara seperti tunduk pada kebijakan penguasa.

Pijakan agama itu digunakan untuk menundukkan dan menciptakan relasi represif dengan rakyat kecil agar mereka ini tidak melakukan atau memproduk sikap dan perilaku yang bercorak ekstremis, radikalis, dan fundamentalis ketika dihadapkan dengan kewajiban-kewajiban yang sudah digariskan oleh negara. Dalam tafsir negara ini, agama diposisikan sebagai 
sumber doktrin yang memerintahkan supaya setiap pemeluk agama sadar, rela, dan bertanggungjawab untuk melaksanakan perintah negara.

Kondisi itu jelas paradoksal dengan doktrin keadaban dan pemanusiaan manusia yang digariskan Pancasila. Atmosfir rentan, terpinggirkan, dan dikalahkan ini membuatnya dan memaksanaya untuk melakukan aktifitas nekad dan bahkan krimialistik. Masalahnya, siapakah yang sejatinya kehilangan keadaban dan prinsip pemartabatan manusia yang diajarkan dalam sila kedua Pancasila?

\section{PEMBAHASAN}

\section{Negara Membutuhkan Ideologi}

Bangsa Indonesia mengenal istilah Pancasila jauh sebelum Indonesia merdeka. Pancasila merupakan Ideologi bangsa Indonesia. Secara harfiah Pancasila terdiri dari dua kata yaitu "Panca" yang berarti lima dan "sila" yang berarti aturan yang melatar belakangi perilaku seseorang atau bangsa, kelakuan atau perbuatan sesuai dengan adab yang dijadikan sebagai dasar. Karena itu, Pancasila berarti rangkaian lima aturan tentang dasar-dasar atau prinsip-prinsip petunjuk perilaku dan perbuatan masyarakat bangsa indonesia. Kelima sila tersebut kemudian berperan menjadi pandangan hidup, keyakinan, atau cita-cita bangsa indonesia yang berfungsi sebagai dasar dalam mengambil suatu keputusan terhadap berbagai persoalan yang dihadapi bangsa indonesia. ${ }^{2}$

Melaksanakan doktrin Pancasila berarti menerapkan dan menegakkan norma-norma yang terkandung dalam setiap sila yang terkandung dalam Pancasila. Dalam setiap sila dalam Pancasila, terdapat doktrin sakral atau suci, yang mewajibkan setiap anggota masyarakat untuk memahami dan mengamalkannya secara maksimal.

Hal itu dapat dipahami dalam Pembukaan UUD NKRI Tahun 1945, khususnya alinea ke empat yaitu: "Kemudianm daripada itu untuk membentuk suatu Pemerintah Negara Indonesia yang melindungi segenap bangsa Indonesia dan seluruh tumpah darah Indonesia dan untuk memajukan kesejahteraan umum, mencerdaskan kehidupan bangsa, dan ikut melaksanakan ketertiban dunia yang berdasarkan kemerdekaan, perdamaian abadi dan keadilan sosial, maka disusunlah Kemerdekaan Kebangsaan Indonesia itu dalam suatu Undang-Undang Dasar Negara Indonesia, yang terbentuk dalam suatu susunan Negara Republik Indonesia yang berkedaulatan rakyat dengan berdasar kepada Ketuhanan Yang Maha Esa, Kemanusiaan yang adil dan beradab, Persatuan Indonesia dan Kerakyatan yang dipimpin oleh hikmat kebijaksanaan dalam

${ }^{2}$ Tobroni dkk., Pendidikan Kewarganegaraan Demokrasi, HAM, Civil Society dan Multikulturalisme, (Malang: Pusapom, 2007), 8. 
Permusyawaratan/ Perwakilan, serta dengan mewujudkan suatu Keadilan sosial bagi seluruh rakyat Indonesia". Dari perumusan di atas dapat diketahui adanya tujuan "perlindungan masyarakat" (social defence) dan "kesejahteraan masyarakat" (social welfare),yang harus tercermin dalam tujuan. $^{3}$

Berpijak pada doktrin dalam Pembukaan UUD itu, idealitasnya setiap subyek bangsa, apalagi kalangan elitis seharusnya mengerti, bahwa dalam realitas sejarah telah mengajarkan, bahwa ujian terhadap ideologi Pancasila tidaklah ringan, namun seabagai amanat yang sangat mulia, karena ada saja pihak-pihak yang berkeinginan menggantikannya dengan ideologi lain atau berbagai bentuk pelanggaran terhadapnya.

Dapat terbaca kondisi riil, bahwa dalam perjalanan ideologi Pancasila, tidak sedikit model perilaku manusia Indonesia atau elemen masyarakat yang menunjukkan pola berfikir, bersikap, dan berperilaku yang berseberangan dan bertentangan dengan doktrin Pancasila, dan bahkan membahayakan negara kesatuan republik Indonesia (NKRI). Akibatnya, ideologi Pancasila seperti menjadi sebuah ideologi yang gagal melaksanakan tugasnya guna membangun keragaman bangsa.

Pancasila, sebagaimana tercantum dalam Pembukaan UUD 1945 dalam perjalanan sejarah kemerdekaan bangsa Indonesia telah mengalami persepsi dan interpretasi sesuai dengan kepentingan rezim yang berkuasa. Pancasila telah digunakan sebagai alat untuk memaksa rakyat setia kepada pemerintah yang berkuasa dengan menempatkan Pancasila sebagai satusatunya asas dan kehidupan bermasyarakat, berbangsa dan bernegara. Masyarakat tidak diperbolehkan menggunakan asas lain sekalipun tidak bertentangan dengan Pancasila. Nampak pemerintah Orde Baru berupaya menyeragamkan paham dan ideologi bermasyarakat dan bernegara dalam kehidupan masyarakat Indonesia yang bersifat pluralistik. Oleh sebab itu, MPR melalui Sidang Istimewa tahun 1998 dengan Tap. No. XVIII/MPR/1998 tentang Pencabutan Pedoman Penghayatan dan Pengalaman Pancasila (P4) dan menetapkan Pancasila sebagai dasar negara. Pancasila sebagaimana dimaksud dalam Pembukaan UUD 1945 adalah dasar negara dari negara Kesatuan Republik Indonesia harus dilaksanakan secara konsisten dalam kehidupan bernegara. ${ }^{4}$.

Mantan Ketua Mahkamah Konstsitusi Mahfud MD pernah menyatakan bahwa terdapat problem serius yang melanda pembentukan dan penegakan hukum di Indonesia, hukum dibuat dan ditegakkan seolah kehilangan nyawa, hukum dengan mudah dirasuki oleh kepentingan sesaat

${ }^{3}$ Muladi dan Diah Sulistyani, Pertanggungjawaban Pidana Korporasi (Bandung PT Alumni, 2013), 33.

${ }^{4}$ Bambang Satriya, Filsafat Pancasila, (Jakarta: Nirmana Media, 2016), 27. 
yang justru bertentangan dengan cita dan tujuan hukum (Pancasila). ${ }^{5}$ Pancasila merupakan ideologi yang "berharga mati" di negara ini. Bukan hanya Negara Kesatuan Republik Indonesia (NKRI) saja yang bernilai "harga mati". Dengan pertaruhan apapun, Pancasila harus dibela sebagai ideologi negara. Dilihat dari aspek filosofis seluruh sistem hukum Indonesia tidak dapat dilepaskan dari pandangan yang menyatakan bahwa Pancasila sebagai Philosophische Grondslag (Grundnorm). ${ }^{6}$ Hal ini membuktikan kemuliaan dan urgensinya Pancasila sebagai ideologi Negara, sehingga sampai pada aspek pembentukan atau pembangunan sistem hukum hingga ke seluruh aspek kehidupan di Negara ini, Pancasila yang dijadikan sebagai sandaran atau rujukan utamanya.

Pancasila sebagai sistem nilai harus dijadikan dasar pembentukan hukum dan pola penegakan hukum di Indonesia. Hal ini disampaikan pada pidato Seokarno yang menyatakan bahwa Pancasila sebagai pandangan hidup (weltanschauung) terdiri dari lima dasar atau lima azas. ${ }^{7}$ Pembentukan sumber nilai yang mewadahi sumber sistem falsafah kebangsaan berjalan dalam sejarah panjang yang melibatkan kaum cendekia dan benar-benar primus inter pares, di samping masyarakat. Proses yang demikian panjang ini menjadi tidak sia-sia atau tidak sampai kehilangan makna karena dogma yang terkandung dalam Pancasila berisikan tentang ajaran kemuliaan dan memuliakan hidup dan kehidupan bermasyarakat dan berbangsa, seperti bagaimana menjadi manusia yang mampu "memanusiakan manusia" atau membuat "Tuhan selalu hidup setiap aktifitas manusia", sehingga diidealisasikan manusia tetap berjalan di jalan yang benar. Dalam ranah demikian, Pancasila merupakan lima dasar yang berisi pedoman atau aturan tentang tingkah laku yang penting dan baik, ${ }^{8}$ yang membuat manusia mengabdi pada kebaikan.

Menurut Teguh Prasetyo bahwa Pancasila mempunyai fungsi konstitutif dan regulatif. ${ }^{9}$ dengan ditetapkannya Pancasila sebagai philosophische grondslag (grundnorm) maka pembentukan hukum, penerapan hukum dan pelaksanaannya tidak dapat dilepaskan dari nilai-nilai

${ }^{5}$ Mahfud MD, Pancasila Sebagai Tonggak Konvergensi Pluralitas Bangsa, Sarasehan Nasional 2011 "Impelementasi Nilai-Nilai Pancasila Dalam Menegakkan Konstitusionalisme Indonesia, (Yogyakarta dan Jakarta: UGM dan MKRI, 2011), 17.

${ }^{6}$ Yopi Gunawan, Kristian, Perkemangan Konsep Negara Hukum dan Negara Hukum Pancasila, (Bandung: Refika Aditama, 2015). 2.

${ }^{7}$ Teguh Prasetyo dan Abdul hakim Barkatullah, Filsafat Teori dan Ilmu Hukum, (Jakarta: Rajawali Pers, 2012). 387.

${ }^{8}$ Maulana Arafat Lubis, Pembelajaran PPKN, (Yogyakarta: Samudra Biru, 2018), 23, dan lihat Ari Tri Soegiti, dkk, Pendidikan Pancasila, (Semarang: Unnes Press, 2016), 2.

${ }^{9}$ Teguh Prasetyo, Ari Pornomosidi, Membangun Hukum Hukum Berdasar Pancasila, (Bandung: Nusa Media, 2014). 36, 
yang terkandung dalam Pancasila. Disamping itu posisi yang demikian telah menjadikan Pancasila sebagai dasar dari sistem hukum bangsa Indonesia yang mencakup 4 hal yaitu, philosophical, political, cultural, dan sociological.

Dalam sistem hukum berdasar Pancasila, teori keadilan bermartabat menemukan bahwa tidak ada Undang-undang yang berlaku di Negara Kesatuan Republik Indonesia yang tidak mencantumkan irah-irah "Dengan Rahmat Tuhan Yang Maha Esa", sehingga menurut Cicero sumber hukum adalah kehendak Tuhan. ${ }^{10}$ Suatu pandangan yang konkret dari teori keadilan bermartabat bahwa keadilan bermartabat merupakan suatu usaha untuk memahami dan mendekati pikiran atau yang disebutkan dalam "ayat-ayat" Tuhan.

Dalam konteks ini teori keadilan bermartabat menolak arogansi namun mendorong rasa percaya diri dan keyakinan diri suatu sistem hukum dalam hal ini adalah sistem hukum berdasarkan Pancasila. Maka dari itu teori ini meletakkan tujuan hukum sebagai keadilan secara sistemik, hukum itu bagi teori keadilan bermartabat selalu adil, selalu bermanfaat dan selalu pasti. ${ }^{11}$

Norma hukum dalam teori ini identik dengan keadilan, artinya norma yuridis dibuat adalah bertujuan untuk menegakkan keadilan. Pada siapa keadilan akan diberikan, didisribusikan, atau ditujukan, maka norma hukum yang dibuat oleh negara diarahkan atau dialamatkan untuk menegakkan (mengabdi) pada keadilan. Dalam ranah demikian setiap subyek bangsa, apalagi kalangan elitisnya mempunyai tanggungjawab besar untuk mewujudkannya. Kalau keadilan bisa ditegakkan, maka kebinekaan tidak akan menjadi ancaman.

Dalam kehidupannya manusia selalu membutuhkan kebenaran, keteraturan, dan keindahan/ kenikmatan. Oleh karena itu ada logika, etika dan estetika yang mencakup penalaran kaidah-kaidah. Kaidah-kaidah tersebut mencakup kaidah agama, kesopanan, kesusilaan dan hukum. Ada beberapa sebab mengapa orang mematuhi hukum; pertama, orang mematuhi hukum karena takut akan akibatnya berupa suatu penderitaan apabila norma tersebut dilanggar. Hukum yang demikian memerlukan sistem pengawasan dari pejabat hukum bukan dari masyarakat. Begitu sistem pengawasan hilang, maka hukum tersebut menjadi disfungsional. Kedua, orang mentaati hukum antara menjaga hubungan baik dengan warga-warga masyarakat lainnya. Hal ini terutama dalam masyarakat dimana hubungan pribadi dan batiniyah antara warganya sangat kuat. Ketiga, orang menaati hukum karena

\footnotetext{
${ }^{10}$ Teguh Prasetyo, Keadilan Bermartabat, Perspektif Teori Hukum, (Bandung: Nusamedia, 2015). 25.

${ }^{11}$ Ibid. 103. 
merasa bahwa kepentingannya terpenuhi atau tidaknya terlindungi hukum. Keempat, orang mentaati hukum karena hukum itu sesuai atau serasi dengan sistem nilai yang dianutnya. ${ }^{12}$

Sistem norma hukum Indonesia berada dalam suatu sistem yang berlapis-lapis dan berjenjang-jenjang sekaligus berkelompok-kelompok, dimana norma tersebut berlaku, bersumber dan berdasar pada norma yang lebih tinggi, dan norma hukum yang lebih tinggi berlaku, bersumber dan berdasar pada norma hukum yang lebih tinggi pula, demikian seterusnya sampai pada suatu norma dasar negara (Staatfundamental norm) Republik Indonesia, yaitu: Pancasila. ${ }^{13}$ Sistem norma hukum yang bersifat heirarkis tersebut bertujuan menentukan derajatnya masing-masing, dengan konsekuensi jika ada norma hukum (peraturan) yang bertentangan maka yang dinyatakan berlaku adalah yang derajatnya lebih tinggi, dalam hal ini berlaku asas lex superiori derogat legi inferiori (hukum yang derajatnya lebih tinggi mengesampingkan hukum yang derajatnya lebih rendah). ${ }^{14}$ Peghormatan terhadap norma yang lebih tinggi ini identic dengan mengajarkan pada setiap subyek bangsa, terlebih anggota DPR, Menteri dan anggota DPD untuk menghormati Pancasila.

Kemerdekaan Indonesia yang dinyatakan dalam proklamasi 17 Agustus 1945 memberi pengertian bahwa mulai berlakunya tata hukum nasional dan tidak berlakunya hukum kolonial. Tata hukum yang baru tersebut dilandaskan pada nilai-nilai luhur Pancasila, sehingga tata hukum itu dapat disebut sebagai sistem hukum Pancasila. Teorisasi hukum secara dan atas dasar Pancasila akan memunculkan teori hukum Pancasila. Teorisasi tersebut terjadi atas dasar kesadaran bahwa pengorganisasian masyarakat didasarkan pada Pancasila, termasuk sistem hukumnya. Penyusunan sistem hukum Pancasila sudah diamanatkan sejak proklamasi kemerdekaan 17 Agustus 1945, khususnya pada bagian pembukaan. Hukum adalah bidang yang paling jelas mendapatkan tugas untuk berbenah atas dasar Pancasila. Hukum dalam menjalankan tugasnya banyak tergantung dan ditentukan pula oleh interaksinya dengan proses dan kekuatan lain dalam masyarakat. ${ }^{15}$

Pancasila merupakan general acceptance of the same philosophy of government dari konstitusi, dengan demikian Pancasila yang menjadi dasar

12 Riduan Syahrani, Rangkuman intisari Ilmu Hukum (Bandung: PT Citra Aditya Bakti, 2011), 17.

${ }^{13}$ Maria Farida Indrati Soeprapto, Ilmu Perundang-undangan: Dasar-dasar dan Pembentukannya, (Yogyakarta: Kanisius, 1998), 39.

${ }^{14}$ Bagir Manan, Teori dan Politik Konstitusi, (Yogyakarta: FH UII Press, 2003), 206.

${ }^{15}$ Sacipto Rahardjo, Pendidikan hukum sebagai pendidikan manusia (Yogyakarta: Genta Publishing, 2009), 124-125. 
norma-norma konstitusional dan harus menjadi pedoman dan orientasi dalam melakukan penafsiran norma konstitusi. ${ }^{16}$ Segala bentuk interpretasi baik ketika melakukan suatu perumusan norma yuridis maupun ketika norma yuridis sudah berhasil dibentuk, tetaplah mengacunya pada konstitusi, karena dalam bangunan konstitusi ini terkandung nilai-nilai Pancasila.

Guruh Sukarno Putra (2005) dalam tulisannya berjudul, "Sekali Pancasila, Tetap Pancasila" menyebutkan, bahwa hingga kini, kita masih diliputi keprihatinan karena hampir seluruh sila Pancasila belum terwujud. Lihat saja, banyak warga mengalami kesulitan menjalankan ibadah menurut keyakinannya. Sila Kerakyatan atau demokrasi belum dihayati, terbukti banyak kekerasan dan kerusuhan. Dampak belum dihayatinya Pancasila, yaitu kebobrokan moral, berdampak pada manusia, alam, dan lingkungan. Alam murka akibat perilaku manusia tidak ramah lingkungan. Bencana alam kecil sampai besar terus terjadi, dari Aceh hingga Yogyakarta. Sebagian orang religius menganggap ini adalah pertanda azab. Orang spiritual menyebut ini karma karena ada sebab-akibat, sedangkan orang yang berpancasila akan menilai, hal ini sebagai pertanda ketidak-adaban manusia yang merajalela.

Pakar bidang antropologi dan budaya I Gusti Putu Artha (2006) dalam tulisannya berjudul "Mewaspadai Delegitimasi Pancasila", juga mendeskripsikan, bahwa perilaku elite politik dan pengelola bangsa ini pun tak sepenuhnya mendukung suburnya semangat kebangsaan itu. Pada praktik wacana, memang benar komitmen para elite untuk mengamankan Negara Kesatuan Republik Indonesia, Pancasila, UUD 1945 dan Bhinneka Tunggal Ika. Bukalah dokumen kampanye para kandidat presiden RI, para calon gubernur dan kepala daerah, komitmen menegakkan negara kebangsaan itu pasti terpatri rapi. Tengok pula komitmen dan sumpah jabatan para wakil rakyat kita, niscaya komitmen kebangsaan itu mereka ucapkan sebelum memangku jabatan. Namun, di wilayah praksis, kita menangkap sebuah paradoks. Pada satu sisi mereka mengakui negara Pancasila, pada sisi lain elite politik kita mengesahkan (membenarkan) perbedaan.

Setiap elemen bangsa semestinya memahami, bahwa Pancasila sebagai dasar negara merupakan hasil kesepakatan para founding fathers yang kemudian sering disebut sebagai "perjanjian luhur" bangsa

16 Mahfud MD, dalam "Ceramah Kunci Ketua Mahkamah Konstitusi Pada Kongres Pancasila Pada Tanggal 30 Mei 2009”, Agus Wahyudi, Rofiqul Umam Ahmad, Saldi Isra, Sindung Tjahyadi, dan Yudi Latif (ed), Proceeding Kongres Pancasila: Pancasila Dalam Berbagai Perspektif, (Jakarta: Sekjend dan Kepaniteraan Mahkamah Konstitusi, 2009), 12-13. 
Indonesia.10 Piagam Jakarta merupakan kristalisasi dari kebudayaan bangsa Indonesia yang menjadi sumber inspirasi dan motivasi para pendiri bangsa untuk membentuk suatu negara merdeka yang lebih baik. Pancasila lahir dari kebudayaan bangsa Indonesia, bukan berasal dari negara lain. Sehingga pada hakikatnya Pancasila merupakan manifestasi bangsa Indonesia yang sudah tumbuh dalam jiwa manusia Indonesia dan kemudian diaplikasikan dalam kehidupan berbangsa dan bernegara. ${ }^{17}$

Soal idealitas negara ini, Siswono Yodo Husodo menyebut, bahwa negara kebangsaan Indonesia terbentuk dengan ciri yang amat unik dan spesifik. Berbeda dengan Jerman, Inggris, Perancis, Italia, Yunani, yang menjadi suatu negara bangsa karena kesamaan bahasa. Atau Australia, India, Sri Lanka, Singapura, yang menjadi satu bangsa karena kesamaan daratan. Atau Jepang, Korea, dan negara-negara di Timur Tengah, yang menjadi satu negara karena kesamaan ras. ${ }^{18}$

Banyak pakar yang mengagumi negeri ini. Nurcholis Madjid (1999) misalnya dalam bukunya berjudul Cita-cita Politik Islam era Reformasi menyatakan, bahwa pluralitas masyarakat Indonesia di berbagai aspek telah menjadi kekayaan tersendiri, yang sebenarnya membuat bangsa ini besar. Kekayaan ini adalah pesona yang bisa dinikmati, jika dapat dijaga dengan sebaik-baiknya, tidak dirusak dan dikorbankan oleh kepentingan egoisme sektoral. Perbedaan seharusnya menjadi aspek mendasar yang mempertemukan persatuan. ${ }^{19}$ Pengakuan cendekiawan ini menguatkan fakta tentang Indonesia, yang sangat pantas dicintai, yang bentuk kecintaan diantaranya harus ditunjukkan dengan mengakui kebinekaan dan merawatnya secara progresif, yang langkah ini menjadi tanggungjawab seluruh elemen bangsa Indonesia, khususnya di kalangan elitisnya.

\section{Sila Kedua, Multikulturalisme, dan Islam}

Jika kalangan pembelajar memahami bacaan Indonesia, tentulah ada pengakuan kalau Indonesia negara besar dan kaya. Merawat kekayaan seperti multikulturalime bukan hal mudah, karena perbedaan dalam menyikapi kebinekaan terkadang membawa pada kondisi ketidakdewasaan dan ketidakcerdasan sebagian elemen bangsa yang terseret pada pengakuan bahwa etnis atau daerah dan kelompoknya yang paling unggul, paling istimewa, paling berhak, atau paling memiliki sumberdaya tertentu,

${ }^{17}$ M. Noor Syam, "Pancasila Dasar Negara Republik Indonesia (Wawasan SosioKultural, Filosofis dan Konstitusional)”, edisi II (Malang: Laboratorium Pancasila, 2000), 3

${ }^{18}$ Farhan Abrori, Menjaga Negara Kesatuan Republik Indonesia (Perspektif Multidimensi), (Jakarta: Hilamcom, 2016), 3.

${ }^{19}$ Ibid, 5 . 
sehingga terseret pada klaim-klaim yang menyudutkan kebersamaan dan keindonesiaan, serta menggugat kesatuan atau berkecenderungan ingin melakukan disintegrasi atau memisahkan diri dari NKRI.

Jika kita membaca konstruksi realitas sumberdaya negara Indonesia, dapat kita pahami dan syukuri, bahwa Indonesia menjadi satu negara bangsa meski terdiri dari banyak bahasa, etnik, ras, dan kepulauan. Hal itu terwujud karena kesamaan sejarah masa lalu, nyaris kesamaan wilayah selama 500 tahun Kerajaan Sriwijaya dan 300 tahun Kerajaan Majapahit dan sama-sama 350 tahun dijajah Belanda serta 3,5 tahun oleh Jepang.

Meskipun realitas multikulturalisme seperti itu, tidak sedikit ujian berbentuk pola-pola radikalitas atau berkecenderungan radikalisme yang terjadi, yang kondisi ini mestinya lebih bisa diprevensi, khususnya radikalitas yang dilakukan oleh rakyat kecil atau subyek bangsa yang tidak atau belum memahami makna kebinekaan.

Pilar-pilar negara tidak akan mudah mencegah "orang kecil" dari kemungkinan ketersesatan opsi yang dijatuhkannya (orang miskin) ke dalam wilayah abu-abu atau kriminalitas baru, bilamana mereka terbiarkan terpuruk dalam ketidakberdayaannya. Realitas demikian ini mengindikasikan kegagalan negara dalam membumikan kesaktian Pancasila yang berorientasi membebaskan atau menjaga kebinekaan.

Ketidakberdayaan itu dapat dibaca sebagai kondisi buruk yang dapat menggiring seseorang atau sekelompok orang terjerumus dalam perbuatan kriminalitas dan radikalisme. Seseorang bisa terbentuk dirinya menjadi preman akibat lingkaran sosial laten bercorak defek, memiskinkan, tidak berkeadilan, dan tidak berkeadaban. Kata Sosiolog A. Halim Mahfudz (2007), orang miskin jadi preman, "orang bayaran" seperti pembunuh berdarah dingin atau melakukan kekacauan tertentu sejatinya bukan karena kemauannya, tetapi karena "digiring" oleh kondisi buruk yang bernama disparitas, ketidakadilan kebijakan, dan "kelalaian" pemerintah (negara), khususnya ketika/telah terbaca kuat lebih memanjakan kaum kaya atau kelompok tertentu. ${ }^{20}$

Langkah khalifah Umar bin Abdul Aziz, yang dikenal sufis ini, barangkali perlu dicontoh oleh pemerintah Indonesia. Umar memang tidak kenal Pancasila, namun ia menunjukkan kepemimpinan Pancasilais. Misalnya Umar selalu melarang anak buahnya hendak memboroskan anggaran belanja negara untuk kepentingan pembangunan benteng dengan kalimat "apalah gunanya membangun benteng kota, kalau kebutuhan masyarakat belum dipenuhi. Bentengilah kehidupan masyarakat dengan keadilan (pemenuhan hak-haknya)"

${ }^{20} \mathrm{Ibid}, 13$. 
Belajar dari peringatan tersebut menunjukkan, bahwa menggencarkan pembangunan fisik perkotaan atau memboroskan anggaran demi membangun gedung-gedung pemerintahan supaya wajahnya menjadi lebih menarik dalam pandangan mata, apalagi sekedar untuk dijadikan investasi kepentingan politik atau menaikkan gengsi elit pejabatnya, jelaslah bukan sebagai model pembangunan dan perilaku elit yang sejalan dengan kepentingan riil masyarakat yang sedang hidup susah dan bersahabat dengan beragam ketidakberdayaan (empowerless). Kondisi demikian potensial mendestruksi kedamaian masayarakat dalam menjalani dan menikmati multikulturalismenya, karena mesti ada banyak orang yang dikorbankan, sementara yang lainnya diuntungkan. Semestinya mereka ini paham, bahwa keberagaman ini harus diutamakna untuk dijaga. Dalam pasal 36 A Undang-Undang Dasar Tahun 1945 setelah diamandemenkan empat kali, yaitu pada tahun 1999, 2000, 2001 dan 2002, dicantumkan kalimat "lambang Negara ialah garuda pancasila dengan semboyan Bhineka tunggal ika". ${ }^{21}$

Masyarakat tidak akan sering, terus menerus, atau secara rutin (sistemik dan terstruktur) menjadi korban dan tumbal hingga menjadi sosok dan komunitas radikalistik, kalau saja subyek kekuasan menunjukkan kemauan dan kemampuannya dalam melakukan aksi-aksi cerdas atau menggalakkan pola manajemen bernegara berbasis sufisme sosial terhadap derita empirik masyarakat, atau elit pemimpi tidak memberi contoh praktikpraktik neoanimalisme (berkebinatangan gaya baru).

Selama subyek kekuasaan belum juga memperkaya pola praksis sufisme (penyucian diri) kenegaraan atau masih meliberalismekan kedurjanaan dalam pengambilan kebijakan, niscaya sulit problem riil masyarakat berhasil diatasinya, termasuk mengakomodsi macam derita orang miskin. Memberi solusi tepat sararan kepada masyarakat yang terhimpit masalah penderitaan dan ketidakberdayaan haruslah diawali dengan pembacaan dan pembedahan obyek secara adil dan berkeadaban, bukan asal memproduk kebijakan, apalagi yang berpola dehumanistik dan diskriminatif.

Derita masyarakat miskin Indonesia atau berpenghasilan rendah sebenarnya sangat mudah dibaca. Laporan Bank Dunia terbaru misalnya menunjukkan, sebagian besar penduduk miskin di Asia Tenggara tinggal di Indonesia . Lebih dari 110 juta orang Indonesia hidup dengan penghasilan kurang dari USD 2 dolar atau kurang dari Rp 19.000 per hari. Jumlah orang sebanyak itu sama dengan total penduduk Malaysia ditambah seluruh penduduk Vietnam dan Kamboja). ${ }^{22}$

\footnotetext{
${ }^{21}$ Maulana Arafat Lubis, Op.Cit, 36

${ }^{22}$ Farhan Abrori, Op. Cit, 13.
} 
Kalau negara (subyek kekuasaan) memang punya kemaupun politik (political will) yang serius dalam mempancasilaisasi secara empirik ke ranah masyarakat, negara tidak akan kesulitan mencari dan menemukan orang miskin. Sayangnya, selama ini masyarakat miskin lebih sering berada dalam atmosfir yang kurang menjadi prioritas di tangan sejumlah subyek kekuasaan sang rezim yang kehilangan nilai-nilai kemanusiaan dan keadaban yang sudah digariskan Pancasila.

Semestinya setiap subyek kekuasaan paham, bahwa UUD Tahun 1945 adalah jabaran dari filsafat negara Pancasila sebagai Ideologi nasional (Weltanschauung), asas kerohanian negara dan jati diri bangsa. Karenanya menjadi asas normatif-filosofis-ideologis konstitusional bangsa, menjiwai dan melandasi cita budaya dan moral politik nasional, terjabar secara konstitusional:

1. Negara berkedaulatan rakyat (negara demokrasi: sila IV)

2. Negara kesatuan, negara bangsa (nation state, wawasan nasional dan wawasan nusantara: sila III) ditegakkan sebagai NKRI

3. Negara berdasarkan atas hukum (Rechtstaat), asas supremasi hukum demi keadilan dan keadilan sosial, oleh semua untuk semua (sila I-II-IV-V) sebagai negara hukum Pancasila.

4. Negara berdasarkan atas Ketuhanan Yang Maha Esa menurut dasar Kemanusiaan yang adil dan beradap (sila I-II) sebagai asas moral kebangsaan kenegaraan RI., ditegakkan sebagai budaya dan moral manusia warga negara dan politik kenegaraan RI.

5. Negara berdasarkan asas kekeluargaan (paham persatuan negara melindungi seluruh tumpah darah Indonesia dan seluruh rakyat Indonesia. Negara mengatasi paham golongan dan paham perseorangan terumus dalam sila III-IV-V) ditegakkan dalam sistem ekonomi Pancasila. ${ }^{23}$

Jika mereka paham dengan amanat yang harus dijalankannya, mestinya relasi kekuasaan yang dibangunnya wajib mengutamakan rakyat, khususnya yang masih hidup kesulitan ekonomi. Masyarakat miskin demikian ini identic telah jadi korban kebijakan atau perlakuan oknum elemen rezim yang sudah lama mematikan ruh Pancasila. Mereka tidak memerintah dengan jiwa populis dan mental akuntabel, dan sebaliknya bangga mengidap penyakit malversasi, yang mengakibatkan masyarakat miskin menjalani kehidupan keseharian dalam ketidakberdayaan dan keprihatinan.

Sejarah telah mengungkapkan bahwa Pancasila adalah jiwa seluruh rakyat Indonesia, yang memberi kekuatan hidup kepada bangsa Indonesia

${ }^{23}$ Noor Syam, Op.Cit, 3 
serta membimbingnya dalam mengejar kehidupan lahir yang makin baik didalam masyarakat Indonesia yang adil dan makmur. Menyadari bahwa untuk kelestarian keampuhan dan kesaktian Pancasila itu, perlu diusahakan secara nyata dan terus menerus penghayatan dan pengamalan nilai-nilai luhur yang terkandung didalamnya oleh setiap warga negara Indonesia, setiap penyelenggara negara serta setiap lembaga kenegaraan dan lembaga kemasyarakatan baik dipusat maupun daerah. ${ }^{24}$

Elemen rezim itu berkewajiban mengubah paradigma hidupnya berbasis Pancasila. Mereka berkeharusan untuk mengalahkan berbagai bentuk gaya hidup dan target-target bercorak pengabsahan status sosialpolitik atau perjalanan karir strukturalnya yang monologis dan eksklusif menjadi basis amanat kerakyatan (kemanusiaan yang adil dan beradab). Mereka wajib menghentikan pola-pola permisifisme seperti kebiasaan mengabaikan amanat membebaskan orang miskin atau memenangkan liberalisme (memainkan) "penyimpangan" atas nama negara, atau praktik pengeliminasian "kemanusiaan yang adil dan beradab".

Nabi Muhammad SAW dan para pendahulu, tidak sedikit yang memberikan teladan empirik mengenai praktik Islam Non-Misoginisme (tanpa kebencian). Pemikir kenamaan Bawa Muhayyadin dalam Islam for World Peace: Eksplanations of A Sufi (1987) menceritakan, ketika Khalifah Umar memasuki kota Jerussalem, Uskup dari Makam suci Kristus menawarkan untuk menunaikan shalat di dalam gereja, namun Umar memilih salat di luar pintu. ${ }^{25}$

Uskup itu bertanya pada Umar, "mengapa tuan tidak mau masuk ke gereja kami?". "Jika Saya sudah salat di tempat suci kalian, para pengikut saya dan orang-orang yang datang ke sini pada masa yang akan datang akan mengambil alih bangunan ini dan mengubahnya menjadi sebuah masjid. Mereka akan menghancurkan tempat ibadah kalian. Untuk menghindari kesulitan-kesulitan ini dan agar gereja kalian tetap terjaga, maka saya memilih salat di luar", demikian penjelasan Umar. ${ }^{26}$

Khalifah Umar itu mengingatkan Uskup itu tentang makna multikulturalisme dan kebebasan beragama atau cara berelasi dengan Tuhan secara inklusif-humanistik, meski Khalifah Umar juga memberikan peringatan (warning) mengenai kemungkinan adanya sekelompok orang yang berlaku radikal dan bermaksud menggsur tempat ibadah.

${ }^{24}$ Kansil dan Christin S.T Kansil, Modul Pancasila dan Kewarganegaraan, (Jakarta: PT Pradnya Paramita, 2005), 21

25 Abdul Wahid, Sunardi, Dwi Ari Kurniawati, Kebinekaan dalam Perspektif Islam, (Jakarta: Nirmana Media, 2017), 56.

${ }^{26}$ Ibid. 
Jika memahami dialog Umar tersebut, khalifah Umar sepertinya menilai, bahwa tempat ibadah merupakan cermin suci dan mendasar bagi komunitas beragama, sehingga ketika Uskup itu menawarkan shalat di dalam gereja, khalifah tidak semata berfikir tentang agama yang sedang dipeluknya, tetapi juga menjatuhkan sikap politik keagamaan yang arif, bening, demokratis, dan prospektif humanistik dan futuristik (bermasa depan da berkemanusiaan), artinya kondisi demikinian inilah idealitasnya di kemudian hari, yang harus ditegakkan pemeluk agama apapun (kesalehan dalam keragaman).

Keputusan khalifah juga bukan dimaksudkan untuk tidak toleran dan apalagi melecehkan terhadap demokratisasi keagamaan yang ditawarkan pihak Uskup, tetapi sebagai wujud advokasi kepentingan komunitas beragama lain dari kemungkinan tangan-tangan radikal dari kelompok lainnya.

Nabi Muhammad SAW pernah mengingatkan relasi universalitas atau multikulturalisme dalam sabdanya, "tidak disebut beriman diantara kalian, sehingga mencintai saudaranya sama dengan mencintai dirinya", yang sabda ini mengajarkan tentang kewajiban mencintai sesama manusia tanpa sekat etnis, politik, budaya, dan agama. Beliau meminta setiap manusia untuk berusaha maksimal menegakkan hak-hak orang lain.

Memahami hal itu, jika pemeluk agama itu memang benar-benar beragama (beriman), maka terlarang hukumnya menciptakan gaya beragama yang mendehumanisasikan dan menterorismekan sesamanya. Setiap subyek kekuasaan negeri ini yang setia pada Pancasila haruslah ditunjukkan dengan model perilaku yang mencitai rakyat dengan sebenar-benarnya dalam "memberikan yang terbaik".

Pemeluk agama lain (yang selain Islam), wajib diperlakukan sebagai subyek yang bertmartabat seperti pola perlakuan yang diberlakukan pada dirinya sendiri, yang sangat memuliakan atau memartabatkan kemanusiannya. Artinya, secara universal atau multikulturalisme, pemeluk agama dari manapun, pastilah mencintai hidup harmoni dan damai dengan sesamanya, sehingga tidak selayaknya menjadikan orang lain menjalani hidup dalam keprihatinan dan ketidakberdyaan, apalagi kalau berposisi sebagai subyek kekuasaan (khalifah), maka tentu kewajibannya menjadi lebih istimewa lagi

Konstruksi relasi kemanusiaan (habluminannas) berbasis kearifan, kecerdasan, dan cinta kasih dengan sesama dalam multikulturalisme, jelas bukan dilandasi oleh kebencian atau dendam, seperti tidak mendisparitaskan status perbedaan agama, etnis, budaya, dan lainnya, karena agama apapun yang dipeluknya atau aspek apapun yang disukai, membuat orang lain bisa hidup bahagia, sejahtera, dan bebas dari bahaya yang menakutkan dan 204 
mematikan adalah kewajiban fundamental juga yang didoktrinkan setiap agama di bumi ini. Doktrin "kemanusiaan yang adil dan beradab" mengajarkan setiap subyek bangsa Indonesia untuk melakukan hal ini. Tidak layak dusebut Pancasilais jika sesama atau banyak anggota masyarakat yang menjadi korban radikalismenya atau adanya diskresi yang menjauhkannya dari keadilan dan kemanusiaan.

\section{PENUTUP}

Tidak ada negara yang tidak punya ideologi, termasuk Indonesia. Pancasila sudah lama menjadi ideologi bangsa Indonesia. Kesaktian Pancasila sudah teruji. Meskipun demikian, masih banyak subyek bangsa ini yang tidak menempatkannya sebagai ideologi yang diikuti atau ditaati. Mereka menunjukkan sikap dan perilaku yang berlawanan dengan ideologi, sehingga layak dikategorikan sebagai pelanggar atau melakukan pelecehan padanya.

Salah satu sila dalam Pancasila yang dilanggar atau dilecehkannya adalah sila kedua (kemanusiaan yang adil dan beradab). Doktrin keadaban dan kemanusiaan ini sangat urgen, karena berpengaruh besar terhadap bangunan dan keberlanjutan hidup manusia dalam kaitannya dengan manusia lainnya.

Bentuk perbuatan yang ditunjukkan dengan melecehkan sila kedua dari Pancasila ini adalah radikalisme baik secara individual maupun kelompok. Pancasila sebagai penjaga multikulturalisme hanya disikapi sebagai kumpulan teks yang tidak bermakna. Bangunan multikulturalisme atau kebinekaan menjadi rentan terkoyak akibat perilaku sebagian elitis bangsa yang tidak melaksanakan atau menegakkan keadilan.

\section{DAFTAR PUSTAKA}

Abdul Wahid, Sunardi, Dwi Ari Kurniawati, 2017, Kebinekaan dalam Perspektif Islam, Jakarta: Nirmana Media.

Ari Tri Soegiti, dkk, 2016, Pendidikan Pancasila, Semarang: Unnes Press. Bagir Manan, 2003, Teori dan Politik Konstitusi, Yogyakarta: FH UII Press. Bambang Satriya, 2016, Filsafat Pancasila, Jakarta: Nirmana Media.

Farhan Abrori, 2016, Menjaga Negara Kesatuan Republik Indonesia (Perspektif Multidimensi), Jakarta: Hilamcom

Kansil dan Christin S.T Kansil, 2005, Modul Pancasila dan Kewarganegaraan, Jakarta: PT Pradnya Paramita.

Laboratorium Pancasila IKIP Malang, 1997, Refleksi Pancasila dalam Pembangunan Surabaya: Usaha Nasional.

Mahfud MD, 2011, Pancasila Sebagai Tonggak Konvergensi Pluralitas Bangsa, Sarasehan Nasional 2011 "Impelementasi Nilai-Nilai 
Pancasila Dalam Menegakkan Konstitusionalisme Indonesia, Yogyakarta dan Jakarta: UGM dan MKRI, 2011.

Mahfud MD, 2009, dalam "Ceramah Kunci Ketua Mahkamah Konstitusi Pada Kongres Pancasila Pada Tanggal 30 Mei 2009”, Agus Wahyudi, Rofiqul Umam Ahmad, Saldi Isra, Sindung Tjahyadi, dan Yudi Latif (ed), Proceeding Kongres Pancasila: Pancasila Dalam Berbagai Perspektif, Jakarta: Sekjend dan Kepaniteraan Mahkamah Konstitusi.

Maria Farida Indrati Soeprapto, 1998, Ilmu Perundang-undangan: Dasardasar dan Pembentukannya, Yogyakarta: Kanisius.

Maulana Arafat Lubis, 2018, Pembelajaran PPKN, Yogyakarta: Samudra Biru.

M. Noor Syam, 2000, Pancasila Dasar Negara Republik Indonesia (Wawasan Sosio-Kultural, Filosofis dan Konstitusional), edisi II, Malang: Laboratorium Pancasila.

Muladi dan Diah Sulistyani, 2013, Pertanggungjawaban Pidana Korporasi, Bandung: PT Alumni.

Riduan Syahrani, 2011, Rangkuman intisari Ilmu Hukum, Bandung: PT Citra Aditya Bakti.

Satjipto Rahardjo, 2009, Pendidikan Hukum Sebagai Pendidikan Manusia, Yogyakarta: Genta Publishing

Teguh Prasetyo, 2015, Keadilan Bermartabat, Perspektif Teori Hukum, Bandung: Nusamedia.

Teguh Prasetyo dan Abdul Hakim Barkatullah, 2012, Filsafat Teori dan Ilmu Hukum, Jakarta: Rajawali Pers

Teguh Prasetyo, Ari Pornomosidi, 2014, Membangun Hukum Hukum Berdasar Pancasila, Bandung: Nusa Media.

Tobroni dkk., 2007, Pendidikan kewarganegaraan Demokrasi, HAM, Civil Society dan multikulturalisme, Malang: Pusapom.

Yopi Gunawan, Kristian, 2015, Perkemangan Konsep Negara Hukum dan Negara Hukum Pancasila, Bandung: Refika Aditama. 